\title{
The Failure of the Mass Media to Construct the Communities in Ledok Wetan and Sumbangtimun Villages, Bojonegoro Regency, Related to the Flood Problem of Bengawan Solo
}

\author{
Mondry \\ Postgraduate Program at Faculty of Social Science and Political Science, \\ Universitas Brawijaya, Malang, Indonesia. \\ Departement of Sociology at Faculty of Social Science and political Science, \\ Universitas Brawijaya, Malang, INDONESIA. \\ Darsono Wiadirana \\ Departement of Sociology at Faculty of Social Science and political Science, \\ Universitas Brawijaya, Malang, INDONESIA.

\section{Sanggar Kanto} \\ Departement of Sociology at Faculty of Social Science and Political Science, \\ Universitas Brawijaya, Malang, INDONESIA. \\ Zulkarnain Nasution \\ Faculty of Education Science, \\ State University of Malang, INDONESIA
}

\begin{abstract}
The mass media is often informed of successfully constructing communities. Many books and journals have written about the success of mass media in constructing the communities. This study, however, examines how the mass media failed to construct the communities of Ledok Wetan and Sumbangtimun Villages, Bojonegoro Regency, East Java, Indonesia in the case of Bengawan Solo floods. The failure was not due to the failure of Berger and Luckmann's theory (2012) of the construction of social reality, but because the communities considered that floods from the longest river in Java were not harmful to human life and not economically harmful. Because of this assessment, the public does not feel worried about doing harmful things, such as throwing garbage into Bengawan Solo. At the same time, the mass media also did not assess the Bengawan Solo floods that occur every rainy season every year, go through 3 cities and 17 districts, and involve thousands of refugees as a serious problem. National mass media did not report the flood problem of Bengawan Solo, while the local media only reported when the flood occurred, between two to seven days. There is no news that aims to inform, educate, and influence the community to better anticipate the floods of the Bengawan Solo, to minimize their impact. In fact, newspapers distributed in the flood victims' communities do not report about flood news.
\end{abstract}

Keywords: Failure, Mass Media, Construction, Flooding, Bengawan Solo River

\section{INTRODUCTION}

Diverse information obtained by communities from the mass media can be attributed to the function of media, which according to the 1999 Principal Law covers entertainment, information, education, and social control (Assegaff, 1983, Mondry, 2008,). In addition, the mass media is able to act as 'actors' who can shape public opinion and becomes a pressure 
group for an idea that must be accepted by other parties (Sobur, 2009). Even in various journals, it is stated that the mass media is able to construct communities through information (including news) that they convey.

On the other hand, mass media in Indonesia have not tried to build public opinion or awareness of the Indonesian people related to natural disasters, despite reporting on various natural disasters. Whereas Beck (1998) explains that all people today are people at risk in environmental problems, evidenced by the frequent occurrence of calamities, whether purely natural events or events involving humans. Many victims have been affected by the natural disaster.

The dry season that was considered as the cause of forest fires in Sumatra and Kalimantan last year caused losses of more than Rp. 2 trillion, not including human casualties (TVOne, 2015). The mass media reported that 23 provinces were hit by floods (Jawa Pos, 2015). That means 64 percent of the provinces in this country are hit by floods that not only hit the lowlands. Large landslide events hit Garut (West Java) on September 21, 2016, which caused many casualties. Floods and landslides, according to Jawa Pos (2016), are the main threat in every rainy season. Poor drainage and chaos in regional governance exacerbate this condition. Until now, however, no area has seriously applied the principle of reducing runoff water (zero runoff).

Deforestation of water storage lands can certainly cause drought. This happened at the Tirta Rimba Nature Park in the city of Bau-Bau, Buton, Southeast Sulawesi, which initially had dense growths, but then became bald and eventually caused the community to lack water (Purwanto, 2007). The problem of deforestation, both official and illegal, has become a world problem. Various calamities that occur due to the process of deforestation occur in many countries. That is because humanity (more than 7 billion people) needs firewood, logs, paper and various other forest products (Brown, 1982).

Indonesia's natural damage does not only occur on land, but also in the sea. Satria (2009) explains that Indonesia has around 18 percent of the world's coral reefs, only 6 percent of which are in good condition. The rest is damaged, including about 30 percent, which has been severely damaged. Southeast Asia today, according to Satria, is the area with the largest damage to the world's coral reefs; of the 150 thousand square kilometers of world coral that were damaged, 40 thousand square kilometers of the amount of damage is present in Southeast Asia. The causes of the damage are many, which may be climate, pollution, mining, or others. Yet, fish bombing activities are often accused of being the main factor.

The mass media with their capabilities have reported almost all interesting events that occurred and then conveyed to the public. Disasters are a kind of news or event that is usually delivered or broadcasted by mass media. According to Heide (Sudarma, 2014), almost 25 percent of news media contained disaster reporting. The data, however, was for developed countries, while for developing countries, including Indonesia, it might not be as such. In addition, mass media has the ability to construct the society, as proven in various national and international journals.

As proof, several national and international journal articles, including Hadiati, Abdullah, and Udasmoro (2013), showed that television media succeeded in accompanying (constructing) viewers to participate in providing an assessment of women involved in corruption cases. Women become considered as people who enjoy wealth. Roem (2011) wrote about the role of 
local media in disaster-prone areas (West Sumatra). The results of his research revealed that local media played a significant role in providing information about disasters to the community, even though various groups of people responded to this differently. The research by Roem was conducted in disaster-prone areas, so the role of local media became quite prominent.

This research relates to mass media and the public regarding news of natural disasters, both national and local. Information in the mass media already exists, but the number is relatively small. National media only preach disasters which according to the editors of the media have a large impact on society. While local media only preach when there is a flood. This is why it is desirable to examine the construction of media in the community related to flood news. The research locations were chosen as Ledok Wetan and Sumbangtimun Villages, Bojonegoro Regency, East Java, Indonesia. The area in Bojonegoro Regency as many as 16 sub-districts out of 28 sub-districts in this district routinely hit by floods from the overflowing Bengawan Solo River

\section{MEDIA CONSTRUCTION OF COMMUNITIES IN RELATION TO FLOODS}

The Bengawan Solo flood that hit the Bojonegoro area occurs every year and has been going on for a long time. But in reality, the mass media did not make the flood from the longest river on Java Island as interesting information to report. All informants (18 people) were chosen because their homes and or fields were flooded every year, stating that they had never known about the news of the Bengawan Solo flood from watching television at home or at the evacuation site during the flood. Only one informant said that he had watched the Bengawan Solo flood news on television, during the 2007 flood.

In fact, what all informants said was true. National television broadcasts, which are most often watched by people in both research locations, can be said to have almost never reported the Bengawan Solo floods that affected 3 cities and 17 districts. National television with information that can be seen in almost all regions in Indonesia, even abroad (such as East Timor) does not seem interested in reporting the Bengawan Solo flood, even though it happens every year. Because the media never preached it

The disinterest of national television in Bengawan Solo floods may be understandable, because the event commonly occurs every year and the impact of floods faced by the people of Bojonegoro Regency is not too large (except for the 2007 flood). When linked to the value of the news, it does not have exceptionality, even though this issue is precisely the rationale for national television to inform about natural disasters. Of course, if explored further, the problem is related to values, specifically news value. Higher news value leads to higher interest from mass media (including television) to report. The slowly rising waters of the Bengawan Solo do not cause heavy currents, property casualties, more fatalities, or even tensions which attracts the public to follow its information on national television.

\section{DISINTEREST OF LOCAL MEDIA}

Local media, both newspapers and news radio in Bojonegoro, only actively provide events when floods occur. Thus, the community only knows the news when the flood has arrived, the aid process has been provided, and the flood recedes. Even the information is not fully known by people affected by the flood, because they generally do not buy newspapers; even in Ledok Wetan and Sumbangtimun Villages, there is no kiosk that sells newspapers, while radio is only for entertainment. As the largest flooded area should be informed about the flooding, including mitigation of the disaster. 
The General Manager of the Radar Bojonegoro newspaper, Ahmad Taufiq (43 years old), as the only newspaper published in the regency, as well as news radio in Bojonegoro, confirmed that information did not appear before the early warning system (Mondry, 2008, p. 85). That is, the media should provide preliminary information about the possibility of flooding that will come to the Bojonegoro area, but the Radar Bojonegoro Newspaper does not do that, because the Bojonegoro community has memorized the estimated flood.

The local mass media in Bojonegoro Regency also did not bring up information about knowledge about disasters, including floods, news after the floods, or anything aimed to make people aware of how to avoid the floods. Taufiq, who is also the former editor-in-chief of Radar Bojonegoro, said that the market share of Radar Bojonegoro is actually the middle- to lowerclass, as is its parent newspaper, Jawa Pos. Yet in the last few years, there has been a decline in the trend of print media buyers, as the current state of print media. In addition, he admitted that the distribution of the newspaper agents was only at the sub-district level, not to the hamlets or villages. Therefore, sellers of Radar Bojonegoro are not seen in Ledok Wetan Village or even in Sumbangtimun Village.

Like almost all other media, Radar Bojonegoro photographed the disaster only when the event occurred, as do others. Thus, the news only appears during the event and its management. It has always been this way. Radar Bojonegoro follows, because the editorial policy did not consider it an important social issue for the community. Journalists also saw that the Bengawan Solo flood event was only partially an event that could be publicly informed. Flood news is thought to be unsuitable or similar. News about the environment only occasionally appears, only at certain moments, but the routine is long-term. The problem with the media related to public awareness does not present itself as a potential problem.

Bramantyo, who is the leader of Radio Madani, one of Bojonegoro's local media, also responded to the same thing. He stressed the impression of the public was that the mass media were not too interested in environmental news and disasters. The media does not seek community problems; "Honest, the target is profit". Because reporters bear the costs, they look for profitoriented news and interesting news, become news that is read, heard, watched, and therefore gets advertisements or sponsors. In fact, it is not true that the mass media ignored the surrounding environment, because the mass media, including Radio Madani, also discussed social and political issues, including the problem of flooding. In accordance with the program, the Bupati was associated with flooding and receiving benefits,

Politics receives funds, especially before this election. If truly abundant, it can supplement the next year's budget. In one year, Rp. 100 million is received. This is only one month from one regent candidate with Rp. 100 million. There are also many candidates. If all entered, it can be Rp. 500 million in total. It is difficult for advertisements to pay; they only paid later. The media is now not rightful in selecting its topics, but incidental and profit-oriented in doing so.

\section{DISCUSSION}

From various information, it can be seen that the national media (especially television) are not interested in the Bengawan Solo flood event because the event is unpopular. The incident did not have a major impact on the community and the conditions were not the same as similar events in other regions.

Horrific events which caused sadness and news to appeal to consumers and should the local mass media really know that. But the Bengawan Solo flood that passes through Bojonegoro and 
other regions every year does not bring extraordinary things to be reported and does not cause an increase in media income

News coverage by local media is based more on proximity to the location of media consumers with the location of the incidents. This is because the community will still follow events that occur close to the community, although not too high. As a result, the mass media through news did not cause construction related to the Bengawan Solo floods, which in the end did not build awareness about the Bengawan Solo floods.

The majority of communities in Ledok Wetan and Sumbangtimun Villages use national television as a source of information. The news aired on national television becomes the information they receive every day. Because news about the Bengawan Solo flood was not shown (if at all very rare), they did not receive information about the news of flooding in their area via television because of the lack of coverage. As a result, people in both villages (including informants) did not get any information about the floods that affected individuals in the area. As a result, their perception of the Bengawan Solo floods did not come from television coverage.

Although the newspaper and radio media in Bojonegoro actively reported floods, even though only when the incidents occurred, similar conditions also occurred in the reporting by local newspapers and radio in Bojonegoro Regency. The news also did not provide much information about the Bengawan Solo floods to the community in the two study locations. The reason is that mass media in these locations, especially newspapers, are not a source of news information for informants in the two research locations.

In fact, when observed, online media are ones that instead report the flooding in Bojonegoro. However, because the media are still small, even accessed by the public at a glance, the information is not well received and is not able to build a certain perception to informants about the floods. Their perception of flooding in the region must have come from experience, from information from communities of the previous generation. The Bengawan Solo floods are not disasters, are not dangerous, could be anticipated, are not harmful, and considered beneficial by some.

The Dictionary of Indonesian Language (Depdikbud, 1995) suggests that perception is a direct response from something or a process by which someone knows several things through the five senses. Sugihartono et al. $(2007$, p. 8) explains that perception is the ability of the intellect to translate stimulus or the process of translating stimulus into the human senses. Humans have differences in perception; some perceive that something is good (positive) or that there is something bad (negative). This will affect human actions in a real manner. He also explained that perceptions are different, as some perceive good things (positive) and bad things (negative). Effendy (Mondry, 2008, p. 80) explains that the function of the press is to inform, entertain, educate, and influence, while Assegaff (Mondry, 2006, p. 23) mentions that the function of the press is for information, entertainment, education, and social control. The function of the press is not wrong, as the theory has been proven in five continents and many countries over the years.

Yet in Bojonegoro, the opposite happened, not because of the theory, but because mass media did not provide enough space for reporting the flood problem in the area. The reality is that the definition does not apply regarding Bengawan Solo floods for informants in Ledok Wetan and Sumbangtimun Villages. The problem is not the definition, but because there is not enough 
coverage from mass media that the community can find out about in both research locations about the Bengawan Solo floods in order establish their perception of the floods.

As a result, the function of the press thus does not occur, because the process of providing information, entertainment, education, and social control or influence, which take a long time, can only influence the changes in society. The same conditions also occur for the issue of construction. The theory of Berger and Luckmann (2012) that regards about the ability of mass media to construct society does not take place in Bojonegoro. This is not because the mass media failed to construct the community. The previous research would have significantly explained, if the mass media had the ability of and succeeded in constructing the community.

This problem occurs because although the Bengawan Solo flood occurs regularly every year, its reports do not appear on national television media, which is in great demand by the public. This is because mass media will generally report information or events that are popular. The incident also did not appear much in local mass media, such as newspapers and radio, although newspapers and radio are not the main news source in Ledok Wetan and Sumbangtimun Villages. Bengawan Solo flood news in local mass media is reported only when significant. There is no special treatment, but the reporting is the same as for other events.

With the basis of news value theory from Santana (Mondry, 2016, p. 153-155), it turns out that there is an important element that causes national television media to be not interested in reporting Bengawan Solo floods, which is the lack or absence of the extraordinary occurrence of the event. The Bojonegoro flood event did not cause major problems, did not cause tensions for television viewers, and did not evoke emotional emotions. It is certainly different from the eruption of Mount Sinabung and Mount Agung, which affected many things.

The same is true in comparison to the earthquake in Lombok, NTB, which caused a great shock by the large number of fatalities and material losses. Not to mention, NTB is now a rising tourism location in the world, following Bali. All of these things are certainly attractive to mass media, not only nationally, but also the world. In fact, the event has become news that is exposed by the mass media continuously. The results are already visible, not only to move the government and the people of Indonesia, but also the international community.

With that theory, actually only one thing makes news of Bengawan Solo floods interesting for the people of Bojonegoro, and that is proximity. The community of Bojonegoro and its surroundings directly experienced the floods. That is, the people of Bojonegoro are interested in the news of the Bengawan Solo floods, which they experience immediately. In theory, an event that is closer to media consumers will increase interest among them.

The theory of Berger and Luckman can also apply in terms of the role of the mass media in constructing society. The three processes of internalization, objectification and externalization can also occur through mass media. Various previous studies also confirmed that mass media managed to construct the community in various activities. Information about the Bengawan Solo flood could continue to be received by the public from the mass media. Various information can certainly be used as an internalization material for people at the research location. Furthermore, the information will be determined by the community and eventually will be raised as an individual externalization to the community.

Yet the process did not work, so the visible impression on the surface is that the mass media failed to construct social reality to the community, regarding the floods of Bengawan Solo in 
Bojonegoro. Furthermore, Berger and Luckmann's theory seems inapplicable in this study. What actually happened at the research location was not that the mass media was not able to construct the community in Ledok Wetan and Sumbangtimun Villages, or that Berger and Luckmann's theory are inapplicable to people in this area. The failure occurred not because of the inability of the mass media or Berger and Luckmann's theory regarding the construction of social reality, but because the mass media did not seriously raise the problem of Bengawan Solo flooding into interesting and sustainable information.

If this was done, it is certainly possible that the results will be different. Understanding the community about the flood of Solo will certainly be better. The success of the mass media in constructing the Bojonegoro community (especially the Ledok Wetan and Sumbangtimun villages) will produce a different perception of the flood. This condition will ultimately have a positive impact on the community and environment in Bojonegoro, especially towards the Bengawan Solo, which is the longest river in Java. The community will not produce waste around the river and may also prepare concrete steps in anticipation of flooding in the coming years.

Mass media through flood news is actually able to build a community in shaping people's awareness and behavior in relation to their environment; The Bengawan Solo flood that hit the Bojonegoro area occurs every year and has been going on for a long time. In fact, even though the mass media did not make the flood from the longest river in Java interesting information to report. The mass media also did not prepare the Bojonegoro community to care about the Solo Bengawan flood and their environment. In fact, it is a big problem if it is understood, because it involves community issues in 20 second-level regions and is related to two provinces, Central Java and East Java

\section{CONCLUSION}

The failure of mass media to construct the community in Ledok Wetan and Sumbangtimun Villages is not due to errors or failures of Berger and Luckmann's theories. But due to mass media coverage was not intensive about the Solo Bengawan flood. Because the mass media still assess the problem of Bengawan Solo flooding is not interesting to report. This study supports the theoretical constructs of social reality proposed by Berger and Luckmann, the construction of new media occurs when the quantity and quality of information or mass media news is quite high

Even if it is explored further, in fact the problem of Bengawan Solo flooding that crosses 3 cities and 17 districts is a big problem. The mass media can have a big contribution in constructing the community about various matters related to the Bengawan Solo.

\section{References}

Assegaff, Dja'far . 1983. Jurnalistik Masa Kini [Journalism in the Current Era]. Jakarta: Ghalia Indonesia Beck, Ulrich.1998. World Risk Society. Cambridge: Polity.

Berger, Peter L, Thomas Luckmann. 2012. Tafsir Sosial Atas Kenyataan: Risalah Tentang Sosiologi Pengetahuan [Social Interpretation of Reality: An Essay of the Sociology of Knowledge]. Jakarta: LP3ES

Brawn, Lester R. 1982. Hari yang Keduapuluh Sembilan [The Twenty-Ninth Day] Jakarta: Obor Indonesia

Breen, Michael, Eoin Devereux. 2003. Setting up Margins: Public Attitudes and Media Construction of Poverty and Exclusion in Ireland. Nordic Irish Studies, Vol. 2.

Depdikbud. 1995. Kamus Besar Bahaa Indonesia [Dictionary of the Indonesian Language]. Jakarta: Balai Pustaka Hadiati, Irwan Abdullah dan Wening Udasmoro. 2013. Konstruksi Media Terhadap 
Mondry., Wiadirana, D., Kanto, S., \& Nasution, Z. (2019). The Failure of the Mass Media to Construct the Communities in Ledok Wetan and Sumbangtimun Villages, Bojonegoro Regency, Related to the Flood Problem of Bengawan Solo. Advances in Social Sciences Research Journal, 6(2) 47-54.

Pemberitaan Kasus Perempuan Koruptor [Media Construction on News of Cases of Female Corruptors] Jurnal AlUlum Vol.13 No. 2, Desember 2013. Gorontalo: IAIN Gorontalo.

Iwashita, Chieko. 2003. Media construction of Britain as a destination for Japanese tourists: Social constructionism and tourism. Tourism and Hospitality Research, Vol. 4, No.4, Special issue on Tourism Research 2002 (July 2003)

Jawa Pos. 2015. 23 Propinsi terendam Banjir [23 Provinces Flooded] (news, 18 November).

Jawa Pos. 2016. Banjir Garut "Tsunami” Kecil [Garut Floods, Small “Tsunami”] (news, 21September).

Jawa Pos. 2016. Drainase Buruk Tata Wilayah Semrawut [Bad Drainage and Chaotic Land Planning] (news, 21 November)

Jawa Pos. 2016. Indonesia Siaga Bencana [Indonesia on Alert for Disasters] (news, 21 November).

Kuswarno, Engkus.2009. fenomenologi [Phenomenology] Bandung: Widya Padjadjaran.

Moleong, Lexy J. 2006. Metode Penelitian Kualitatif [Qualitative Research Methods]. Bandung: Remaja Rosda Karya

Mondry, 2006. Komunikasi Media Massa Dalam Pembangunan [Mass Media Communication in Development]. Malang: YPN/Sofa Press

Mondry, 2008. Pemahaman Teori dan Praktik Jurnalistik [Understanding of Theories and Practices in Journalism]. Bogor: Ghalia Indonesia

Mondry, 2016. Pemahaman Teori dan Praktik Jurnalistik [Understanding of Theories and Practices in Journalism]. (second edition) Bogor: Ghalia Indonesia

Roem, Elva Ronaning. 2011. Persepsi Masyarakat Tentang Peran Media Cetak Lokal dalam Mitigasi Bencana Alam [People's Perceptions on the Role of Print Media in the Mitigation of Natural Disasters]. Jurnal Ilmu Komunikasi, vol. 9 no. 2, May-August.

Satria, Arif. 2009. Ekologi Politik Nelayan. [Ecology Politics of Fishermen] Yogyakarta: LkiS

Sobur, Alex. 2009. Analisis Teks Media: Suara Pengantar untuk Analisis Wacana, AnalisisSemiotik, dan Analisis Framing [Media Text Analysis: Introduction to Discourse Analysis, Semiotic Analysis, and Framing Analysis]. Bandung. Remaja Rosdakarya.

Sugihartono, dkk. 2007. Psikologi Pendidikan [Educational Psychology]. Yogyakarta: UNY Press

TV One. 2015. Kerugian Kebakaran Hutan trilyunan Rupiah [Trillions of Rupiah Lost in Forest Fires]. (news, 26 September).

Zuhkra, R.M. 2015. Mekanisme Koping Perawat dalam Menghadapi Stress Kerja di Intensive Care Unit (ICU) RSUD Arifin Achmad. Pekanbaru: Studi Fenomenologi dalam Menghadapi Stress Kerja di Intensive Care Unit (ICU) RSUD Arifin Achmad [The Coping Mechanism of Nurses in the Intensive Care Unit of Arifin Achmad Hospital]. Pekanbaru: Studi Fenomenologi in repository. usu.ac.id/bistream/ 123456789/ .../4/ chapter\%20ll.pdf. 